\title{
Respiratory arrest during dipyridamole stress testing
}

\author{
Graham S Hillis, Abdallah Al-Mohammad, Kevin P Jennings
}

\begin{abstract}
Summary
There is an increasing usage of radionuclide scanning to assess myocardial perfusion, with dipyridamole, the most commonly used stress agent. Although this is an effective, and usually very safe, means by which to assess myocardial blood supply, there have been several incidents of acute bronchospasm in asthmatic patients. There have, however, been no previous reports of respiratory arrest occurring in patients with emphysema. This case illustrates the dangers of administering intravenous dipyridamole, or even adenosine, to patients with chronic lung disease.
\end{abstract}

Keywords: dipyridamole, stress testing, chronic obstructive airways disease, respiratory arrest

Dipyridamole/myocardial scintigraphy is a well-established, and increasingly utilised, technique for the evaluation of myocardial perfusion; particularly where exercise stress testing is not feasible. Dipyridamole is a phosphodiesterase inhibitor with complex activities, including potent coronary artery vasodilatation. ${ }^{1} \quad$ This identifies ischaemic myocardium by maximising regional differences in perfusion. Although it has a good safety record, ${ }^{2}$ there have been isolated reports of acute bronchospasm, ${ }^{3,4}$ though only one previously reported case of respiratory arrest. ${ }^{5}$ We report a case of respiratory arrest following intravenous dipyridamole in a patient with emphysema and discuss the implications.

\section{Case history}

A 59-year-old woman with a history of recent anterior myocardial infarction was referred for a dipyridamole - tetrofosmin myocardial perfusion scan. Following successful early thrombolysis her electrocardiogram had returned to normal but it was felt appropriate to assess the extent of any residual myocardial ischaemia. Previous pulmonary function testing had revealed severe emphysema with no reversibility following inhaled bronchodilators (table), precluding an adequate treadmill exercise test. Approximately half-way through the administration of intravenous dipyridamole $(0.56 \mathrm{mg} /$ $\mathrm{kg}$ over $4 \mathrm{~min}){ }^{6}$ and prior to the injection of the radio-isotope, her breathing became erratic and her level of consciousness fell. The infusion was terminated but she deteriorated
Table Lung function results

\begin{tabular}{|c|c|c|}
\hline Lung function parameter & Patient value & $\begin{array}{l}\text { Predicted va- } \\
\text { lue }\end{array}$ \\
\hline $\mathrm{FEV}_{1}(\mathrm{l})$ & 0.5 & $1.8 \pm 0.4$ \\
\hline FVC (1) & 1.5 & $2.4 \pm 0.4$ \\
\hline $\mathrm{FEV}_{1} / \mathrm{FVC}(\%)$ & 33 & $74 \pm 6$ \\
\hline PEFR ( $1 /$ min $)$ & 80 & $319 \pm 70$ \\
\hline RV (l) & 3.4 & $1.5 \pm 0.3$ \\
\hline VC (l) & 1.7 & $2.4 \pm 0.4$ \\
\hline TLC (1) & 5.1 & $3.8 \pm 0.5$ \\
\hline RV/TLC (\%) & 67 & $38 \pm 6$ \\
\hline$\underset{\left.\mathrm{kpa}^{-1}\right)}{\mathrm{tCO}\left(\mathrm{mmol} \cdot \mathrm{min}^{-1}\right.}$ & 1.9 & $6.5 \pm 1.2$ \\
\hline $\begin{array}{l}\mathrm{kCO}\left(\mathrm{mmol} \cdot \mathrm{min}^{-1} .\right. \\
\left.\mathrm{kpa}^{-1}\right)\end{array}$ & 0.44 & $1.68 \pm 0.20$ \\
\hline
\end{tabular}

Abbreviations: $\mathrm{FEV}_{1}=$ forced expiratory volume in $1 \mathrm{~s}$ $\mathrm{FVC}=$ forced vital capacity; $\mathrm{PEFR}=$ peak expiratory flow rate; $\mathrm{RV}=$ residual volume; $\mathrm{VC}=$ vital capacity; TLC $=$ total lung capacity; $t C O=$ transfer factor for carbon monoxide; $\mathrm{kCO}=\mathrm{tCO}$ per unit lung volume. ${ }^{\star} \mathrm{FEV}_{1}$ following inhaled bronchodilator $=0.51$.

rapidly, sustaining an acute respiratory arrest. She was resuscitated using a 'bag and mask' and recovered spontaneous respiration without requiring endotracheal intubation. Cardiac output was maintained and respiratory examination revealed hyperinflation but no evidence of bronchospasm. Cardiac monitoring demonstrated sinus rhythm throughout with no subsequent evidence of myocardial damage. Arterial blood gases confirmed type II respiratory failure with a chest X-ray showing clear but hyperinflated lung fields. There was no history of previous exposure to dipyridamole or other drug allergy. She made an uncomplicated recovery.

\section{Discussion}

Respiratory problems during dipyridamole stress testing, although rare, should be recognised as a potentially fatal complication. Previous cases have occurred almost exclusively in patients with underlying asthma. ${ }^{3,4}$ There has been one report of fatal respiratory arrest in a patient with chronic obstructive airways disease, although in this case apnoea was preceded by severe bronchospasm. ${ }^{5}$ Likewise, the only documented episode of respiratory failure requiring ventilation following intravenous adenosine was in a patient with chronic obstructive airways disease and, again, this was preceded by bronchospasm. ${ }^{\text {? }}$

Dipyridamole potently inhibits the uptake of adenosine by erythrocytes and endothelial 
cells. ${ }^{1}$ In asthmatics, adenosine is a direct bronchoconstrictor. ${ }^{8}$ This was originally documented after inhalation but has also been reported following intravenous administration..$^{9-11}$ In addition, adenosine exerts a central respiratory depressant effect. ${ }^{12}$ The lack of a history suggestive of bronchial hyperreactivity, the absence of bronchospasm and the deficient response to inhaled $\beta$-agonists all suggest a central cause in our patient. However, direct bronchoconstriction cannot be entirely excluded and a combination of the two mechanisms seems most likely. Our patient recovered without the administration of theophylline, though direct antagonism of the receptor sites makes this the preferred treatment for dipyridamole-induced adverse reactions. ${ }^{2,13}$

With the increasing usage of stress-myocardial scintigraphy, clinicians should be aware of the potential complications of intravenous dipyridamole. Respiratory problems may occur in any patient with obstructive lung disease, including those in whom bronchial hyperreac-

1 FitzGerald GA. Dipyridamole. $N$ Engl f Med 1987; 316: 1247-57.

2 Beller GA. Dipyridamole thallium 201 imaging. How safe is it? Circulation 1990; 81: 1425-7.

3 Eagle KA, Boucher CA. Intravenous dipyridamole infusion causes severe bronchospasm in asthmatic patients. Chest causes severe bro

4 Ranhosky A, Kempthorne-Rawson J and the Intravenous Dipyridamole Thallium Imaging Study Group. The safety of intravenous dipyridamole myocardial perfusion imaging. Circulation 1990; 81: $1205-9$.

5 Ottervanger JP, Haan D, Gans SJM, Hoorntje JCA, Stricker BH. Bronchospasme, apnoe en hartstilstand na een dipyridamol-perfusiescintigrafie (Bronchospasm, apnoea and heart stoppage after perfusion scintigraphy with dipyridanole). Ned Tijdschr Geneeskd 1993; 137: 142-3.

6 Association of the British Pharmaceutical Industry. Data Sheet Compendium 1995; 245-6.

7 Burkhart KK. Respiratory failure following adenosine Burkhart KK. Respiratory failure following aden
administration. Am $\mathcal{J}$ Emerg Med 1993; 11: 249-50.

\section{Summary/learning points}

- dipyridamole-radionuclide scanning is a useful method of assessing myocardial perfusion, particularly where standard exercise testing is impracticable

- intravenous dipyridamole should be avoided in patients with asthma or chronic obstructive lung disease

- dobutamine may be a safer alternative stress agent in patients with lung disease

- adverse reactions to dipyridamole should be treated with theophylline

Box

tivity is not a prominent feature; not only asthma sufferers, as has been previously suggested. ${ }^{3}$ Furthermore, patients with chronic obstructive airways disease appear to be those at greatest risk of severe complications. In such patients dobutamine may be a safer and equally effective myocardial stress agent.

$8 \mathrm{Ng}$ WH, Polosa R, Church MK. Adenosine bronchoconstriction in asthma: investigations into its possible mechanism of action. Brf Clin Pharmacol 1990; 30 (suppl 1): 89S 98S.

9 DeGroff CG, Silka MJ. Bronchospasm after intravenous administration of adenosine in a patient with asthma. $\mathcal{F}$ Pediatr 1994; 125: 822-3.

10 Drake I, Routledge PA, Richards R. Bronchospasm induced by intravenous adenosine. Hum Exp Toxicol 1994; 13: $263-$ 5.

11 Cerqueira MD, Verani MS, Schwaiger M, Heo J, Iskandrian AS. Safety profile of adenosine stress perfusion imaging: results from the Adenoscan Multicenter Trial Registry. $f$ Am Coll Cardiol 1994; 23: 384-9.

12 Eldridge FL, Millhorn DE, Kiley. JP. Antagonism by theophylline of respiratory inhibition induced by adenosine. f Appl Physiol 1985; 59: 1428-33.

13 Mann JS, Holgate ST. Specific antagonism of adenosineinduced bronchoconstriction in asthma by oral theophylline. Br f Clin Pharmacol 1985; 19: 685-92. 